This is the version of the chapter accepted for publication in Hiddleston, Jane and Ouyang, Wen-Chin, (eds.), Multilingual Literature as World Literature. London: Bloomsbury, pp. 282-303. (Bloomsbury Literature as World Literature) https://doi.org/10.5040/9781501360121.ch-16

Accepted version downloaded from SOAS Research Online: http://eprints.soas.ac.uk/33417

Re-use is subject to the publisher's terms and conditions

16.

\title{
Configurations of Multilingualism and World Literature
}

\section{Wen-chin Ouyang}

The history of English is a fascinating field of study in its own right, but it also provides a valuable perspective for the contemporary study of the language [...] This historical account promotes a sense of identity and continuity, and enables us to find coherence in many of the fluctuations and conflicts of present-day English language use. Above all, it satisfies the deep-rooted sense of curiosity we have about our linguistic heritage. People like to be aware of their linguistic roots.

David Crystal $^{1}$

The making of English is the story of three invasions and a cultural revolution. In the simplest terms, the language was brought to Britain by Germanic tribes, the Angles, Saxons and Jutes, influenced by Latin and Greek when St Augustine and his followers converted England to Christianity, subtly enriched by the Danes, and finally transformed by the French-speaking Normans. From the beginning, English was a crafty hybrid, made in war and peace. [...] The English have always accepted the mixed blood of their language. There was a vague understanding that they were part of a European language family, but it was not until the eighteenth century that a careful investigation by a gifted amateur linguist began to decipher the true extent of this common heritage.

Robert McCrum, William Cran, and Robert MacNeil ${ }^{2}$

The proliferation of the conceptual category of 'nation' and its attendant 'national identity' in the colonial and postcolonial age of nationalism has had a long-lasting impact on how we think and speak both of language and literary expression. Monolingualism, albeit a vision of the human linguistic condition invented to allay the anxiety generated by the imagined 'confusion of languages' in Babel, has imposed itself on our imaginings of language and nation, particularly in the 
connection between them. An Arab, for example, is someone who speaks the Arabic language, which in turns defines the Arab nation. Monolingualism of the imagined nation and national subject, it may be argued, is the logical ramification, perhaps even radicalization, of the remedy to Babel's 'confusion of languages' offered by 'monotheistic communities' that fantasize about an original language that would serve as the glue of their union and at the same time mark their return to the Godly paradise. Monolingualism may offer comforting coherence and cohesion, as David Crystal observes, but it also suppresses our natural multilingualism and the complexity of our linguistic ecology. It generates the kind of emotional, linguistic and intellectual conundrum Derrida describes and interrogates in Monolingualism of the Other OR The Prosthesis of Origin. ${ }^{3}$ The discourse of 'identity' and 'coherence', underpinned by the 'nation' in postcolonial identitarian politics, imposes on both the speaking subject and environment the type of monolingualism that pushes aside and suppresses their multilingualism and multiple identities. This monolingualism has persisted in theories and practices of world literature. World literature, vaguely conceptualized as a canon of universal classics, takes shape as national literary works that travel around and arrive in the world by the Casanovan means of translation into English or French in order to reach London, New York and Paris. ${ }^{4}$ Recent interventions from the perspective of multilingualism, whether of the world, such as Orsini's 'multilingual local', 5 or of literature, such as the heterolingualism, plurilingualism and translanguaging we read about in this volume, move away from the Damrosch's 'translation' as 'mode of circulation'" and Moretti's 'distant' 'mode of reading ${ }^{7}$ to close engagement with the multilingualism of the world outside and created in a literary work, of its author, and even of its nation. The literary work is the site of a confluence of languages and reflects both the multilingual speaking subject and the plurilingual ecology. More importantly, it is the creative effect of languages coming into dialogue.

The locus of multilingualism in these interrogations of world literature remains the speaking subject, the linguistic construction of the literary text, and the language environment in which it is created and gets creative. This chapter rather locates multilingualism in the very fabric of language itself, using the history of each language, such as Robert McCrum, William Cran, and Robert MacNeil's notion of English as 'mixed blood', to peel away the monolingual discourse of 'identity and coherence' constructed around the nation, and to theorize world literature variously. 
Both 'world' and 'literature' are, here, multilingual, so is its worlding. The multilingualism of world literature's inherent worlding allows for extending our field of vision to a longer temporary trajectory inclusive of the contemporary and beyond and to a broader spatial canvas encompassing Europe and elsewhere. The different configurations of multilingualism in each language, when examined comparatively, as I will argue and demonstrate, make it possible to produce meaningful close readings of worldly literary works, to situate their worlding and worldliness in, for example, the words, things, concepts, ideas and ideologies that travel as part and parcel of language, to see a plurality of world literature across time and space, and to delineate the contours of each on the basis of the configuration of multilingualism inherent in its language.

How do we see the Arabic language as inherently multilingual, however? It may be obvious that the Arabic language has lived in a variety of multilingual environments and the history of its development as interactions with other languages from the ancient Near Eastern civilization and Greek philosophy, biblical Hebrew, medieval Latin, Persian and Turkish, and modern European languages. The Arabic language is, like English, 'a crafty hybrid, made in war and peace' but the Arabic speakers have never acknowledged the 'mixed blood of their language'. This is because Arabic is the language of the Qur' an and as such a lingua sacra. Moreover, Arabic has always been able to domesticate any foreignness through its impeccable grammaticality: its systemic grammar can in time smooth out awkward translations from foreign languages; and its extensive and complex morphology allows for the creation of Arabic words that parallel their foreign counterparts. Grammaticality, as Kees Versteegh shows, has absorbed other languages into Arabic in a seamless fashion and made it into the lingua franca of the educated Arabic speakers worldwide. ${ }^{8}$ The grammatical Arabic language is for Karla Mallette an 'Alexandrian' or 'Metropolitan' language that is neither dead nor alive, like Latin in pre-modern Europe, in that it is used for literary writing not for day-to-day communication, but that it has a farther reach historically and geographically than the living languages surrounding them. ${ }^{9}$

By this logic, Arabic necessarily and inevitably renders multilingualism into monolingualism, making multilingualism traceable only, as I have already noted above, to the speaking subjects, the language environment, and the composition of the literary work. The monolingual veneer of grammatical Arabic, even of the highest 
literary register, is never total. There are moments in the history of Arabic language, more particularly, of Arabic writing, which allow us to catch glimpses of various configurations of multilingualism in Arabic and, more importantly, of the ways in which multilingualism is internalized into monolingualism. For my purposes in this chapter, I look at two different but overlapping moments of Arabic multilingualism. Each moment is what Francesca Orsini would call 'multilingual local', however, the 'local' here is not only 'significant geography' but also 'momentous history'. This 'multilingual local' is at the same time connected to a global network of circulation. The triad underpinning this 'multilingual local'-its location in geography, history and global network of circulation - circumscribes the languages in use and gives it a particular configuration of multilingualism.

The first such 'multilingual local' is the eighteenth-century Western Mediterranean represented by Moroccan ambassador and traveller, Muhammad b. 'Uthmān al-Miknāsī (d. 1799), ${ }^{10}$ and the second the nineteenth-century Eastern Mediterranean epitomized by Syrian-Lebanese itinerant translator, Aḥmad Fāris alShidyāq (1804-1887). Both have left behind a complex body of writing that, if read comparatively - diachronically within the works of the same author and synchronically between the two authors - will give us what we look for. These two authors travelled extensively around the Mediterranean, in Europe and the Middle East. They give accounts of experiences abroad in more than one travelogue and, intriguingly and significantly, recast their travelogues written in the conventional rihla genre into the highly literary but also conventional maqāma genre. In what I call the maqāmatasation of the riḥla, the multilingual fabric of al-Miknāsī and alShidyāq's travel writings is transformed into what any unsuspecting reader would see as 'authentic' Arabic, 'grammaticalized', syntactically and morphologically, in such a way that no trace of 'foreignness' is easily detectable. The maqāma in the rihla is, however, punctuated by a sense of crisis, here, both moral and intellectual, expressed as an anxiety about sexuality. This sexuality in al-Miknāsī and al-Shidyāq is, upon close scrutiny, the manifestation at once of apprehension of and excitement about cultural encounter, or entanglement with the 'other' not only socially, morally, and intellectually, but also linguistically. In the interstices between languages, multilingualism, which is here arguably an entanglement of languages, is associated with sexual promiscuity, even though it is at the same time felt as pleasurable and creative. Sexuality in al-Miknāsī and al-Shidayāq is more akin to Roland Bathes' 
'secondary sexuality' that is situated not in sex but in language and thought, or what he calls 'the pleasure of the text', for language is inseparable from thought, ${ }^{11}$ and multililingualism from intercultural conceptual entanglement.

\section{Riḥla and Maqāma}

Al-Miknāsī wrote three travelogues: al-Iksīr fi fikāk al-asīr (Elixir for the Ransom of [Muslim] Captives) documents his travels to and from Spain for the purpose of ransoming captives (1778-1780), ${ }^{12}$ al-Badr al-sāfir li-hidāyat al-musāfir ilā fikāk al-asārā min yad al- 'aduw al-kāfir (Unveiled Full Moon for Guiding the Traveller to Ransom [Muslim] Captives from the Hands of Their Infidel Enemies) recounts his travels to Spain and the Kingdom of Sicily and Naples for a similar purpose (1781-1783), ${ }^{13}$ and Ihrāz al-mu 'allā wa l-raqūb fì hajj bayt allāh al-ḥarām wa ziyārat al-quds al-sharīf wa l-khalīl wa l-tabarruk bi-qabr al-habīb (Lofty Sanctuary and Guardian for Pilgrimage to the Sacred House of God and Visitation of the Noble Jerusalem and Anointed Friends and Seeking Blessings at the Tomb of God's Favourite Messenger) describes his travels to Istanbul as an ambassador and of his pilgrimage to the Islamic holy lands in Palestine and Mecca and Medina (1785). ${ }^{14}$ In these works, al-Miknāsī follows in the footstep of the earlier, more than century old Arabic travel writing on geographical discovery, adventures at sea and in exotic lands, pilgrimage, and the journey in search of knowledge, and of the more recent diplomatic missions to Europe to ransom Muslim captives. ${ }^{15}$

The latter type, the diplomatic missions (to ransom Muslim captives from their Christian captors in Spain, Malta, Kingdom of Sicily and Naples) developed in the aftermath of the Reconquista, most likely after the fall of Granada in 1492. The fall of Granada, and the Jewish and Muslim exodus this precipitated, led to the migration of Andalusis to the Maghreb and their resettlement there. Anadalusi immigrants were linguistically equipped to return to Spain and go to Europe as ambassadors on behalf of the Moroccan Sultans. Al-Miknāsī was heir to a long, complex tradition of travel writing by which the Maghreb is known. Andalusians and Maghrebians (including Moroccans, Algerians and Tunisians) made frequent journeys to the Mashreq, as the prevalent view goes, to learn from the eminent scholars established at the major centres of learning in the Mashreq and, more importantly, to visit the Islamic holy lands. The emergence of 'modern' Europe, and the 'Christian' European empires (Portuguese, Spanish, Dutch, English and French) starting in the fifteenth century and 
ending only in the twentieth century, redefined Christian-Muslim relations (not to mention Christian-Jewish, Muslim-Jewish, and Muslim-Muslim relations) in a variety of ways. The travellers partook in the process and left records of it for us.

Al-Miknāsī's three travelogues, al-Iksīr, al-Badr al-sāfir, and Ihrāz al$m u$ 'allā, offer a glimpse of the kind of travel writings that were taking shape between the sixteenth and eighteenth centuries: records of ambassadorial missions to Europe, in particular, Spain, Holland, France, Kingdom of Sicily and Naples, including Malta, such as those I have already mentioned; and of those to Istanbul, which necessarily overlap with pilgrimage and journey in search of knowledge. ${ }^{16}$ The diplomatic mission underpinning these travel narratives, always explicitly stated but never clearly detailed, distinguishes these Moroccan 'travels to the East' from their Algerian and Tunisian counterparts, even as they all similarly describe the pleasures and hardships of their journey, places, especially 'famous' cities, they visit, and the scholars and luminaries they meet and talk to, and more importantly, they all quote extensively, densely from books they have read about the landmarks on their itineraries and the scholars with whom they come into contact. ${ }^{17}$

Al-Shidyāq wrote two travelogues: al-Wāsiṭa fì ma 'rifat aḥwāl māliṭa (1836) and Kashf al-mukhabba' 'an funūn ürūbbā (1866; completed 1857). ${ }^{18}$ They are, however, more in line with the Arabic genre of travel writing familiar to readers of journeys of discovery and in search of knowledge. ${ }^{19}$ These two texts are the records of al-Shidyāq's experiences in European metropolitan capitals, such as London and Paris, and rural towns, such as Cambridge, of his observations of European cultural institutions unfamiliar in the Middle East and North Africa, such as theatre and musical concerts, of the manners and customs in Malta, Britain and France, of his encounters with Orientalists and their knowledge and practices, of his life as a traveller, and of his views of culture and civilization and the role of gender relations in them. Like al-Miknāsī, who reiterates al-badr al-sāfir in the five maqāmāt appended to it, al-Shidyāq re- and parallel-wrote his two travelogues in al-Sāq 'alā al$s \bar{a} q(1855)$ in the form of an elaborate game of language play, and again in the four maqāmāt embedded in al-Sāq. ${ }^{20}$

$A l-S a \bar{q}$ is arguably al-Shidyāq's fictionalized autobiography ${ }^{21}$ that is structured around his travels from 'Ashqūt, the village where he was born in Lebanon under the Shihābīs in 1804 or 1805, to Egypt, more specifically Cairo and Alexandria, then to Malta, England (with focus on London, Cambridge and Oxford) and France (specially 
Marseille and Paris), followed by Tunis and finally Istanbul, where he died in 1887. The bulk of $a l-S \bar{a} q$ follows the trajectory of his two works on his travels to Malta and Europe, where he gives simultaneously similar and different accounts in al-Wāsita and Kashfal-mukhabba'. In fact, it does not go beyond the historical and geographical scope of these two travelogues, for it was published in 1855 when he still lived in Paris, while he was still working on Kashfal-mukhabba'. It is, however, is a complex multigeneric work modelled on the classical Arabic adab literary tradition. Made up of chapters $(f u s \underline{u} l)$ that combine travelogue with poetry, risāla (epistle), maqāla (as in treatise), hikāya (story akin to The 1001 Nights), interpretation of dreams ( $t a{ }^{\prime} b \bar{r} r$ ), debate (muhāwara), gharīb al-lugha genre of writing on lexical items and semantic oddities in the Arabic language, lexicography, and much more, it is full of digressions that give shape to and are shaped by the variety of linguistic topics and literary motifs and genres he mobilized. It is precisely this feature of al-Sāq that has generated much discussion and debate, as we see in the huge body of literature on the nineteenth-century nahda structured around this text and al-Tahțāwī's (1801-1873) Takhlīs al-ibrìz fì talkhịs bārizz (The Extraction of Gold in the Summation of Paris, 1830). Intriguingly, a maqāma appears as the thirteenth chapter in each of the four sections of $a l-S \bar{q} q$.

\section{Maqāma in Rihla: Politics of Cultural Encounter}

Al-Badr al-sāfir and al-Sāq are not the earliest or only Arabic works that overlap the travelogue, rihla, with the picaresque, maqāma. Rather, they are latecomer to 'play' with genres in Arabic writings. Andalusian Lisān al-Dīn Ibn alKhați b (1313-1374) cast his three travels in al-Andalus and the Maghreb in the form of three maqāmāt, including Khatrat al-tayf (Spectral Visions) The maqāma is a highly diverse literary genre that has served as, according to Philip Kennedy, 'a nexus of interests' for centuries. ${ }^{22}$ Its popularity is attested by its continuous use not only in Middle Eastern languages (Arabic, Hebrew, Persian and Turkish) but also European, especially in Iberia, such as Catalan and Castilian from the tenth century to the twenty-first century, by its expansive geographical spread from Asia across Africa to Europe, and by its openness to any 'topic under the sun'. Its 'fictive', 'rhetorical', and 'polemical' mode or 'irony' has placed it at the forefront of 'subversion' 23 of all and every kind. The maqāma is a re-iteration of the riḥla in both al-Miknāsī and alShidyāq. In both the dialogization of rihla, written in a language closer to the 
vernacular packed with foreign words and concepts, and maqāma, rendered in the highly literary ornate rhyme prose with no trace of foreignness, in the rihla text is expressive of cross-cultural politics and an attendant anxiety about cultural encounter. While the rihla delights in cultural encounter and particularly the creative energy generated in intercultural linguistic and conceptual entanglement, the maqāma in the rihla dramatizes the encounter with foreignness, with foreign languages, concepts, ideas, worldviews and cultural institutions, but in the form of a staged performance of a sexualized melodrama in which foreignness is at once othered as the alluring European or Europeanized woman and integrated into a grammaticalized monolingualism.

Riḥla: Intercultural Linguistic and Conceptual Entanglement

Al-Miknāsī's European travelogues anticipate the tropes to be found in the genre of 'voyage en occident' in the nineteenth- and twentieth-centuries, one of the most famous of which is that of al-Shidyāq. Like all Moroccan travelogues to Europe between the seventeenth and twentieth centuries, ${ }^{24}$ al-Iksīr and al-Badr al-säfr bring home news of the 'cultural institutions' unique to Europe at the time, from monasteries and nunneries, marriage customs and inheritance laws, border quarantines, to hospitals, weapon factories, elite clubs and even opera-houses. AlShidyāq does the same in al-Wāsița and Kashfal-mukhabba'. Their narratives of travel are packed with foreign words and descriptions of European cultural institutions. Names of persons, places, and cultural institutions are transliterated, or transcribed in Arabic words according to how the authors heard the European sounds and spoke their own language(s). Al-Miknāsī called the ruler of Malta 'al-țāghiya' (despot), which does not appear in al-Shidyāq, the Spaniards 'Ișbāniyūl' (as opposed to Egyptian and Levantine 'isbān' or 'isbāniyūl' with a soft 's'), quarantine 'karantīna' (as opposed to Levantine 'karantīna'), and opera 'al-wubra' (as opposed to Egyptian and Levantine ' $\bar{u}$ bir $\bar{a}$ ') and 'al-kumidiya' (as opposed to Egyptian and Levantine 'al-kūmìdiya'). However, they have to invent a new language to describe the unfamiliar cultural institutions and convey their attendant concepts and practices.

When both al-Miknāsī and al-Shidyāq saw and experienced European opera for the first time, the first European opera house in the Arabic speaking world had yet to be built (the Khedival Opera House in Cairo opened in 1871). This is how al- 
Miknāsī describes the opera house he was invited to in Naples and the opera he attended:

The despot (al-tāghiya) invited us one day to see a spectacle they make called Opera (al-wubra), which is known among the Spaniards as Comedia. [...] We found them [the seats] covered with cushions, looking over a huge roofed room. The seats looking over this room were evenly arranged in seven levels $($ tabaqa $t) .[\ldots]$ In one of the corners of the [Opera] House, there was a space lifted by half a human height from the ground. It was paved with wood, and

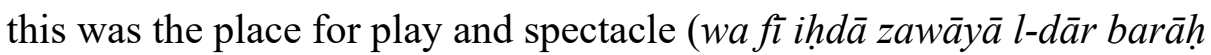
muttasi ' murtafi' 'an al-arḍ bi-naḥw nișf qāma mafrūsha bi-khashab, wa huwa mawdi al-la'b wa l-furja). They had draped a curtain over it, separating it from those in the [Opera] House. [...] Musicians began to do their work, the curtain was lifted, and a spacious house with chairs, domes, stables and levels appeared, and people, women and men in luxurious dress, emerged from all its corners. A woman came forward and began singing with a man. They took turns and brought us wonder and marvel. ${ }^{25}$

Al-Miknāsī is clearly working hard to find a language to convey his first experience of opera. The Arabic term, Dār al-Ūbira, had yet to become common knowledge, and the same goes for theatre, masrah, stage, khashabat al-masrah, and play, masrahiyya. In the absence of the technical terms that would be developed in the nineteenthcentury and standardized in the twentieth, such as acting, tamthil, he turns to the word $l a c b$, to convey the idea of performance.

Al-Shidyāq, who seemed to have had better familiarity with European opera, theatre and musical concerts, had to resort to elaborate descriptions and approximations in order to convey what he experienced. Drury Lane Theatre is malhā, a noun of place Arabs of the nineteenth-century coined from lahw, play or entertainment, to denote theatre. What is represented on stage is tamthil, to make an example of something, before the term became common as acting. A play is $l u$ ' $b a$, a literal translation of English, and actors are players, $l \bar{a}^{\prime} i b \bar{u} n$, Props, enumerated as the dizzying array of instruments ( $\bar{a} l \bar{a} t)$, tools (adawāt) and scenes (manāzir), had to be explained through an elaborate approximation. What if one were to represent the story of al-Samaw'al (first half of the sixth century), legendary for his loyalty to the pre- 
Islamic warrior poet and prince, Imru' al-Qays (501-544), and al-Ḥārith Ibn Zāāim, the Ghassanid prince, who was known to have demanded that al-Samaw'al hand over Imru' al-Qays's properties and especially his armour? A castle would have to be built, three actors resembling the historical figures found, trained, and dressed appropriately for their roles, the armour brought on stage and two scenes set up. In the first, Imru' al-Qays would entrust al-Samaw'al with his possessions, both reciting from their poetry, and in the second al-Samaw'al would refuse to hand over the armour to alHaanrith and watch the latter behead his son, all the while reciting from their poetry. More importantly, al-Shidyāq carves out words from Arabic roots to explain what 'acting' means.

The most amazing thing one sees in the actors and actresses (al-lā ibin wa l$l \bar{a} i b \bar{a} t)$ is that an old man impersonates a young man (yatafattā) through clothing, body language and speech so thoroughly that you think what you see is a young man. And a young man can impersonate an old man (yatashayyakh) so well that you imagine that you see an old man before you. If they appear in front of you afterwards you cannot recognize any of them. They even change their voice, accent, face and hair to pretend to be hunchbacked, lame, ill, asleep, blind, drunk, weeping, laughing, stupid, mad. ${ }^{26}$

He gets creative with his explanation in Arabic. Playing with Arabic morphology, he uses form five, tafa "ala, to give us the sense of impersonation. The pattern itself means 'to inhere a characteristic or quality', and by putting the root of $f a t \bar{a}$, youth, in a verbal pattern of this form and attributing it to an old man, shaykh, al-Shidyāq gives us a rather visual and visceral sense of an old man impersonating a young man in the verb, yatafattā, to inhere youthfulness. He similarly uses form six, tafā 'ala, the pattern of which means 'to pretend', to translate 'acting' into Arabic words that conjure up images of physicality but also follow patterns of Arabic rhyming. The examples he gives, to pretend to be 'hunchbacked, lame, ill, asleep, blind, drunk, weeping, laughing, stupid, mad', fall into a pattern that repeats the sounds of 'wa yatafā 'alūn' several times: wa yataḥādabūn wa yata 'arajūn wa yatamāraḍūn wa yatanāwamūn wa yata 'āmmūn wa yatasākarūn wa yatabākūn wa yataḍāhakūn wa yatah̄āmaqūn wa yatajānnūn. In each instance, a defect with physical manifestation is evoked. 
In this type of creative fun, language and thought are entangled, and multilingualism, here, dialogues among languages, does make for a slippery ground. 'Travelling along linguistic boundaries,' Rebecca C. Johnson observes of al-Sāq, 'alShidyāq pieces together an unruly patchwork of a text whose unity is in danger of disintegration, threatening to dissolve into mere 'ujmah, or "babble." ${ }^{27}$ Such a world literature text, 'a dynamic constitutive process', Johnson further notes, 'creates trouble — generic and otherwise — and it is always in danger of collapse'. ${ }^{28}$ This trouble, whether linguistic, generic, conceptual, or cultural, as I mentioned above, finds expression in the form of a melodrama of man-woman encounter steeped in sexual anxiety. This anxiety is a translation of the contact and interaction with European women in the open public space, where European men and women flirt, court and make love expressively and freely, transcribing the sexual mores of the Europeans into the local, the site from which they depart on their journey and to which they return. The local becomes, in al-Miknāsī and al-Shidyāq's travel narratives, the site of linguistic, conceptual and cultural, entanglement, where little stands on firm ground. Al-Miknāsī's records in al-Badr al-sāfir a moment of moral danger when he finds himself attracted to the lead female singer of the opera he attended and flees. ${ }^{29}$ Al-Shidyāq likewise brings up the danger of the European model of gender relationship on his own gendered moral universe. As he extols the educational and cultural value of European theatre, he is apprehensive of its effect on women attendees. 'Women will learn techniques and tricks to attract men's attention and hang on to their attachment', al-Shidyāq cannot help but observe the charisma of men and women actors, and the type of romantic plays put on stage, 'and they [women] will soon swap their inattentive husbands for the passionate lovers they see before them' ${ }^{30}$ This anxiety-ridden ambivalence pervades the maqāmāt al-Miknāsī and al-Shidyāq refashion out of their travelogues and, more importantly, serves as the trope around which each explores the perils and pleasures of cultural encounter.

\section{Maqāmāt: Crisis of Morality in al-Miknāsī}

Al-Miknāsī wrote the accounts of his travels in Europe and al-Andalus three centuries after the Reconquista and the Andalusi migration to the Maghreb, although more than a century before al-Andalus would become embedded in the Moroccan identity - which would come later in the colonial and postcolonial invention of identity. ${ }^{31}$ Coming from a family of learning in Miknas, would have easily been heir 
to the subversive Andalusi tradition of maqāma writing. He also lived under the Alaouite dynasty (founded in 1631) and served three sultans: Muhammad (Ibn 'Abdallāh) III (1757-1790), al-Yazīd (1790-1792) and Slimane (1792-1822). Muhammad III initiated a set of judicial reforms to cleanse the society from corruption. ${ }^{32}$ Al-Miknāsī's al-Badr al-sāfir is the culmination of three centuries of post-Reconquista Muslim travels in Europe - and we have yet to unearth this material fully - and it describes in great detail the European alterity manifest in their cultural, civic, technological, religious and social institutions and practices. The observations, relatively free of judgment, are an integral part of a narrative of, in al-Miknāsī's language, Christian-Muslim encounter that reproduces the names of places, characters, practices and cultural institutions, as I have already explained, in the particular way Maghrebians at the time transcribed French, Italian and Spanish in Arabic letters.

These foreign words and more disappear completely from the five maqāmāt. Each maqāma focuses on a dramatic moment of al-Miknāsī's encounters not with the foreign but with Muslims residing in Christian lands and whose behaviour invited censure. The expression of indictment of Muslim behaviour, and in fact, moral depravity in turn reflects the practices subject to Muhammad III's juridical reforms. Al-Miknāsī's maqāmāt do not subvert his rihla, but tap into an anxiety lurking beneath the surface of the accounts of his travel, precipitated by what he witnessed in Spain, Malta, Sicily and Naples (with France in the background), and heightens this anxiety into a scandal, as I will show, through a process of 'translation,' linguistically (there is very little biographical information on al-Miknāsī and it is not clear whether he knew European languages or not) and culturally, which is in turn repackaged through another process of 'translation' visible only in the juxtaposition and parallel reading of his rihla and maqāma, of the former's muted descriptions against the latter's vociferous, melodramatic rhetoric-the maqāma is the enclave of classical Arabic $b a d \bar{\imath}^{\prime}$ rhetorical devices and theatrics.

The rihla records two moments of extreme anxiety for its protagonist. In the first instance, the ambassador meets a certain Muhammad al-Hāfi in Malta, also a Moroccan ambassador sent to gather Muslim captives and await their ransom and transport back to Muslim lands. Al-Ḥāfĩ seems to have outstayed his welcome but more crucially he treats his fellow Moroccan ambassador with disrespect and 
manoeuvres to take possession of the ransom money. ${ }^{33}$ In the second instance, he meets the star of a concert he is invited to, a female singer, and feels her allure. ${ }^{34} \mathrm{He}$ bids a hasty farewell to his host and leaves in a hurry in order to escape the trappings of passion, or qabla al-wuqū 'fi habā'il al-hawā wa l-i 'tiqāl in his own words, ${ }^{35}$ which may be translated into 'before falling into the traps of passion and detention' in English. These two episodes are, unlike the rest of the travelogue, rendered in the rhyme prose of the maqāmāt punctuated by quotations from the classical Arabic poetic tradition. The two anxieties, the first about the reprehensible behaviour of his fellow Muslim, countryman, and diplomat in the land of Christians, and the other about his susceptibility to the sexual temptation of a beautiful Christian woman, are collapsed into one in the maqāmāt, a huge anxiety about exposure of private parts in public or to prying eyes. The five maqāmāt, written in a highly satirical tone, retell the rihla but transforms the encounter with the Christian other to that with the Muslim self and re-write the two anxious episodes in the rihla into dramas of 'shame'.

The narrator is, one may argue, the alter ego of al-Miknāsī who performs the function of the itinerant narrator-protagonist of the traditional maqāma genre, and narrates his travels and encounters with the same eloquent con artist, the other protagonist of the traditional genre, at every city he visits, and together they unravel the absurdity of prevalent dogmas and attendant cultural practices. Muhammad alHāfî is fictionalized into Ibn Jallūl al-Tayyib, another Moroccan ambassador in Europe. He is portrayed as a dirty old man and a traitor from within, but not in the conventional sense; rather, he is an opportunist who flouts the proper conduct of a Muslim ambassador in the Christians. Instead of carrying himself with pride and dignity, treating others with magnanimity and generosity but in fairness and observance of rank and file, and upholding what is right, he brings ridicule to himself and the Muslims. As would be expected of the maqama genre, the narratorprotagonist meets the narrated-protagonist in every city he visits and sojourns. The first maqāma, located in Morocco, sets up the character of Ibn al-Jallūl against the backdrop of a moral canvas according to which a Muslim is judged, but here only relevant to his conduct before the Christian other. The second maqāma, also set in Morocco but more specifically in Rabat, introduces Ibn Jallūl's 'malice' (khubth), playing with his nickname, al-Ṭayib, which means both noble and good, and shows the ways in which Ibn Jallūl's penchant for giving false, self-serving evidence invite censure and punishment. He is even ordered slapped, 'saf', which is title of the 
maqāma, al-Ṣaf'iyya, in public. The fourth maqāma, called the Crucifix (alSalībiyya), takes place in Malta, and shows us the hypocritical nature of Ibn Jallūl, who would profess to be a Christian under duress, but would be in the end cast out of both communities. What happens to Muslim reputation if such a dirty old man is the Muslims' ambassador to the Christians? The third and fifth maqāmāt melo-dramatize this inherent anxiety.

The third maqāma, al-Zaytiyya or al-Șüriyya, referring to the wax of stolen candles and the pictorial representation of the thief, takes place in Naples, where the narrator-protagonist arrives as a Muslim ambassador. There he is supposed to meet the con artist, an eloquent man of letters who always inadvertently makes a mockery of ruling political, social and cultural structures, but instead, and yet again, Ibn Jallūl al-Ṭayyib, a dirty old man who, like Muhammad al-Ḥâfì, is a traitor from within. This old man, Ibn Jallūl al-Ṭayyib, steals the candles every night as soon as they are lit, and when caught and interrogated, replies that burning candles was 'wasteful' (iq $\bar{a} d$ al-sham ' min al-saraf). ${ }^{36}$ Worse, this Muslim old man degrades himself further by eating up a storm at meals he is not invited to, and walking in the streets in tatters that expose his private parts. Portraits are made of him in such a state and hung on the walls of marketplaces for all eyes to see. The narrator has to bribe the portrait maker and have him take down these shameful portraits and promise never to produce more. The reversal of the character of the con-artist, one of the two protagonists of the maqāma genre, to a shameful, scandalous old man, who does not seem able to stop himself from stealing or baring himself in public and to the Christians in the Lands of the Christians, speaks of al-Miknāsī’s anxiety about how the Muslims are viewed by their Christian others. What we read in this particular dialogization of rihla and maqāma is a forecast of the Muslim humiliation to come. The Muslims are themselves taken to task for their shameful behaviour. Shame in the maqaimatisation of the rihla is expressed in the form of exposure in public of private parts in the very sight of the Christians, strangers to the Muslims, and outsiders to their community, in a multilingual and multicultural context.

The fifth maqāma, al-Dhabiyya, escalates this fear of exposure to that of entanglement, that of being tempted to have sex with strangers. This last maqāma, which is the longest of the five in fifty-eight pages, ${ }^{37}$ is yet another melodramatic iteration of the entire riḥla, in fact, al-Miknāsī’s three travels, including their itineraries, but shorn of all references to the other. Dense with references to classical 
Arabic writings from prose and poetry, it invokes the ethos of Arabic $a d a b$ writings. Two ethical principles are of particular interest: care for fellow Muslims during Pilgrimage or in Christian lands and loyalty to Islam. It understandably indicts hypocrisy, when Muslims kowtow to Christian for self-preservation or gain, or convert to Christianity under pressure. Two vignettes in this long maqāma recasts alZaytiyya, which is two and a quarter pages: ${ }^{38}$ Ibn Jallūl al-Tayyib is a thief, but here he steals silk pillows from his Christian hosts, ${ }^{39}$ and he is a lecherous old man who spies on the private parts of his Christian host's wife when she is relieving herself only to be forced to stand naked in public as his punishment. ${ }^{40}$ These vignettes are woven into one and re-written from the perspective of khubth, or malice as a moral judgement on both Christians and Muslim hypocrites. Dhabiyya, the noun in the title of the maqāma, is interpreted to mean 'morally reprehensible conduct', ${ }^{41}$ has a wide semantic range in Arabic. Fly, the insect, $d h u b \bar{a} b$, is derived from the same root, so is the verb dhabba, which means to move around and not settle in any place, or to push something away from another thing, to defend, particularly women and the harem. All these meanings are collapsed into one and mobilized to produce a satire in the traditional maqāma style of two creepy crawlers, one indignant Christian husband and another the Muslim dirty old man, who partake in an act of mutual voyeurism.

The maqāma begins thus. The household of Ibn Jallūl, alternately called alkhabith, wakes one morning to feeling that someone has been crawling around the place at night. The investigation leads to a Christian who suspects that his wife is having a liaison with the man of the house. It then transpires that Ibn Jallūl happened upon the Christian's wife in the toilet and peered at her private parts. He accepts standing naked in public as his punishment but unfortunatelya Christian painter makes a portrait of him. The narrator-protagonist, as in al-Zaytiyya, bribes the portrait maker and buys off all the copies so as to douse the scandalous fire. The introduction of a woman, and here of someone whose privacy is violated by a stranger creeping about in the sanctity of her own home, is revealing of a moral crisis of a particular type. In the playful overlap of the notions of women folk, harim, their sanctuary at home, haram, and sanctity, harām, propriety in sexual conduct comes to be synonymous with religious, national and personal honour. The vulgarized sex in al-Miknāsī’s maqāmāt — the dirty old man's voyeurism and nudity — reads like his overreaction to his own sexual attraction to the European female singer he met in Naples. But as we learn from Barthes, sexuality in literary texts, what he calls 'secondary sexuality', is 
located not in sex but in language and thought, or 'the pleasure of the text'. The pleasure of this text, al-Miknāsī's maqāmāt, is the effect of the cultural encounter between European Christians and Maghrebian Muslims in the eighteenth-century that created a stir, in this case, in the language and thought of al-Miknāsī. The apprehension about Muslim honour is tinged with the attraction to the Christian other. The allure of the other can only be spoken of as anxiety-provoking sexual attraction. This anxiety is expressive of the fear of entanglement not only of the body but also of language and thought.

The maqāma in the rihlla moves cultural and linguistic encounter from exteriority (rihla) to interiority ( $m a q \bar{a} m a$ ), from externalization to internalization, from describing and mimicking foreign concepts and sounds to translating these through a language steeped in the Arabic literary tradition, $a d a b$, grammatically, rhetorically, aesthetically and ethically, into a crisis of morality. In the inward facing maqāma, multilingualism is subsumed under monolingualism, and the exuberance of cultural encounter so palpable in the rihla is muted, reduced to unwelcome sexual desire and anxiety of entanglement, as if multilingualism, which unavoidably remaps both language and thought, is promiscuity, but of the 'confusion of languages' type which demands that it be reined in and disciplined into 'coherence'. The dialogism between rihla and maqāma in al-Miknāsī dramatizes the tension between multilingualism as exhilaration and confusion on the one hand, and monolingualism as continuity and coherence on the other. The creative craze generated by translanguaging goes hand in hand with multilingualism. The five maqāmāt are born in the dialogues taking place between al-Miknāsī’s Arabic, its structures of thinking, feeling, and socialization, its poetics and ethics, and the Maltese, Italian and Spanish languages he heard, the technologies, cultural institutions, and social customs he witnessed and experienced in Europe.

It may not be possible yet to articulate the multilingual poetics in these maqāmāt in any concrete sense without us knowing al-Miknāsī’s readings in European languages. However, the theme of shameful Muslim behaviour in Christian lands is the product of the eighteenth-century, as it would disappear in nineteenthcentury Arabic texts, in which the 'West' and 'East' would also replace 'Christian' and 'Muslim' as descriptors of the two parties of the intercultural encounters. But the paradoxical anxiety about entanglement in language, thought and social world would remain. It is a constant in $a l-S \bar{a} q$ 'alā l-sāq, al-Shidāq's re-write or parallel narration 
of his travels around the Mediterranean. While $a l-S \bar{a} q$ 'barely veils an allusion to sexual positions and raunchy anatomical synonyms that the book lists and relists at length in its opening pages, ${ }^{42}$ al-Wāsita and Kashfal-mukhabba 'are free of sexual innuendos even in their observations of European women and gender relations. $\mathrm{Al}$ $S \bar{a} q$ has been subject to extensive, close scrutiny and is acknowledged as 'interlinguistic and inter-textual blending of at least two languages and two poetic traditions in one bilingual literary work', which 'translat[ed] European writings and languages within its neologistic, monolingual textual fold', just like al-Badr al-sāfir, but more recognizably 'represented a philological, translational, literary and narratological tour de force that seamlessly blended the rigid fixed forms and abstruse idioms of high classical Arabic with modern neologisms, the corporeal bawdiness of Rabelais, the blues-tinged poetics of Du Bellay's nostalgia, colourful descriptions of Mediterranean travels, unflattering depictions of the filth of pre-Haussmannian Paris, the sexual mores of nineteenth century Parisians, and unprecedented dialogical forays into gender identity and feminine equality and sexuality in Arabic'. ${ }^{43}$

Al-Sāq 'alā l-sāq: The Anxiety of Interlingual Poetics in al-Shidyāq

Readers and critics of al-Shidyāq have all observed his 'obsession' with women. The body of writing he has left behind is saturated with observations of, comments on, and positions regarding women's status in both Europe and the Arab East, their social conditions, familial roles, relationship with men and, more significantly, with their attention to their body, whether in the way they dressed, wore jewelry, held themselves together at home and in public, or took care of their physical appearance. The progressiveness of his views is often situated in his laying bare (ta 'riya) the Arabic language, stripping it of belles-lettrist embellishments, returning it to its fundamentals, and reviving its innate rigour and richness. This is equally seen in his liberal attitude towards women. He advocated women's education, work and social freedom even before, for example, Qāsim Amīn (1865-1908), considered father of Arab feminism for his pioneering call for the liberation of women in Tahrīr almar'a (1899) and al-Mar'a al-jadīda (1900). Al-Shidyāq's rather explicit references to sex and sexuality of both men and women, especially in al-Sāq, is taken not as a symptom of his debauchery (mujūn) ${ }^{44}$ but instead as a sign of his profound understanding of the importance of women in subject formation, and the role of subject in social and cultural change, in modernization. ${ }^{45}$ Bringing East into 
modernity, according to the messages between the lines and behind al-Shidyāq words, is necessarily premised on the emergence of a 'modern subject' 46 which requires exposing Eastern masculinity, stripping it bare (al-ta 'arr $\bar{l})$, effected here through impersonating woman, going deep into femininity, in order to begin a 'journey of transformation'. ${ }^{47}$ This 'journey of transformation' of the 'modern subject' is understandably seen as the crux of the matter in al-Sāq.

His travel accounts in al-Sāq, as well as in al-Wäsita and Kashfal-mukhabba', are taken in their totality as narrative of an encounter between two cultural spheres informed by a critical distance rather than a bedazzled enthrallment with the European allure. The centrality of women in al-Shidyāq's narratives of European-Arab encounter is responsive not only to a cultural other but also to a profound epistemological and ontological difference. Gender comes to be the site on which this profound epistemological and ontological difference is grappled with and articulated. Here, gender is not merely a signifier of sexual difference but also a way of thinking, gendered thinking, and its radical consequences in knowing and living. At stake is what he calls tamaddun, a 'civilized' state of living centred in the city, that must be grounded in individual freedom that is too often subject to the hegemony of the authority of political and religious institutions as well as 'Tradition' ( 'âdāt wa $\operatorname{taq} \bar{a} l \bar{l} d$ ), and in economic health and social cohesion. What he saw during his travels, in his encounter with difference, are offset against familiar habits and customs, seen, examined, thought of, grappled with, and transformed into a vision. This vision is a 'moral universe' articulated in the form of melodrama, or dramatization of woman's struggle to find a balance between virtuous living, including responsibility towards her husband, children and society, and happiness founded on personal freedom. The merits and vices of both European and Arab models of society, seen through the microcosm of man-woman relationship, are served on a platter, chewed, spat out, and chewed again, all in an attempt to manage the moral dilemmas thrown up in the liminal space opened up in the meeting between two cultures, in the possibility of choice.

Al-Shidyāq writes at length about courtship and marriage in Malta where he lived for fourteen years in al-Wāsița, ${ }^{48}$ highlighting the divergent practices between the Maltese and Arabs. ${ }^{49}$ He first observes that men and women cohabit for a long time in Malta before they marry, sometimes up to three years or more. He discusses the advantages and drawbacks of such a practice from the perspectives of both the 
Arab East and Europe. Marriage without [first] seeing the girl and knowing her circumstances is a most disadvantageous custom especially among the Christians because they do not allow divorce. No good can come out of long cohabitation outside marriage either. The girl would conduct in such a model way until she is married, when she knows that divorce is possible, she would then behave however she pleases. Maltese women are, in his view, lacking in moral uprightness. They often chase after handsome men without thinking of the consequences. They do not respect their husbands. They often contradict their men, correct them and make them look stupid in the presence of others. When they speak to their men, they often raise their voice to such an extent that an outsider is shocked into silence. These themes recur in his comments on English and French women, many of whom he met in Malta, in Kasfh al-mukhabba'. He scrutinizes them further, and in a very class-conscious fashion, during his respective stays in England and France, having been given opportunities to socialize with them. He notes their differing way of managing physical appearance at home and in the street, on an ordinary day or at a dinner party, of relating to their husbands in both private and public, of conducting themselves with men and women outside their immediate family circle, of hosting afternoon tea parties or evening feasts, of conserving or squandering their husband's fortune, and of working, whether farming the lands, selling vegetables and fruits in the street, assisting in shops, serving in restaurants and bars, performing on stage in theatres, or even prostituting.

Even though al-Shidyāq is disturbed by the unpredictable outcome of European courtship before marriage and its attendant potential moral depravity, he is an advocate of both mixed society and courtship before marriage. Al-Shidyāq gives a tacit nod in al-Wāsiț and Kashfal-mukhabba' to mixed society in Malta, England and France.$^{50} \mathrm{He}$ inscribes this in $a l-S a \bar{q}$. His alter ego al-Fāriyāq's marriage to alFāriyāqiyya is preceded by a lengthy courtship on the shared rooftop of their separate abodes. ${ }^{51}$ Every time they have a disagreement during their marriage and he gets angry and ready to denounce her, he would remember those days on the rooftop, then calm down and be ready to talk to her again. Falling in love aside, this pre-marital courtship allows the potential couple to get to know each other and find out if they are suitable for a life-long partnership, and to avoid the kind of shock a groom or a bride experience when they come face to face with each other for the first time on their wedding day, as often happens in the East and even in Malta in the past. However, 
compatibility, both of the individuals concerned and the society of which they are members, is perhaps a more important consideration. He approves of the English practice of pairing young women and men closer in age, as opposed to what occurs in the East, where a man can easily marry a woman at least twenty years younger. Compatibility is here seen as the foundation of good partnership. However, partnership requires, in addition to affection and compatibility, mutual trust, companionship, respect and support.

In these matters, he sees English women as a cut above French women, even though French women are more beautiful and charming - they do pay a great deal more attention to their appearance, wear more glamorous clothes and jewelry, and have better conversation in company. He admires an English woman's modesty-she remains plain except at dinner parties, her diligence in the domestic sphere, her economy in expenditure, and her willingness to take a job in order to help her husband. Unlike her French counterpart, she plays no emotionally manipulative games (hiyal wa makāyid) with her husband or others, and she constantly defers to him. In a telling anecdote, he speaks of exchanging gifts with an English family. 'If you receive a gift from an English family and go the next day to give your thanks, the lady of the house would always defer to the husband, even when he is not at home, and say that the gift is from both of them, ${ }^{52} \mathrm{He}$ is similarly impressed with the respect she shows her husband in public. This kind of respect goes both ways among the English. English men are equally respectful of their wives in both private and public.

There is, it is apparent, an idealized men-women relationship informing alShidyāq's written observations of English, French and Maltese women. As he watches them and compares them with Eastern women, very rarely spoken of explicitly in his travel writing, he is concocting a recipe for what he would consider a model man-woman relationship that can serve as the foundation of tamaddun (civilization, or modernity here). For this relationship is the smallest but most fundamental building block of society. The soundness of this building block, as he later articulates in an article (maqāla) he wrote for $a l-J a w \bar{a} i b,{ }^{53}$ is reliant on compatibility now defined as based on women's accessibility to education and work.

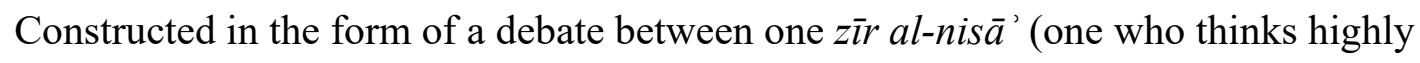
of women) and another bakhis al-nis $\bar{a}^{\prime}$ (he who belittles women), he makes an argument for women's right to education and work. Education would qualify her to 
share his views, worries and welfare, which would in turn cement their friendship and love and avert infidelity. It must come from reading and writing first, then mixing in society, including men, from whom she may learn not just information but also how to be wise. She would then be able to steer away from following superstitions in her conduct, gossip mongering among friends and relations, stirring up discord in society, and manipulating her husband. Women should work for a living too, for work performs the same function and has the added benefit of improving the economic condition of the household. More importantly, she would now be too busy to think of spending on unnecessary things, especially those that satisfy only her vanity, such as expensive clothes and accessories, make up and perfume, and jewelry. But perhaps what is most important is that she can now be the good mother who will teach what she knows as well as by example.

In this, al-Shidyāq is no different from his nineteenth-century contemporaries, who advocated the liberation of woman through her education for the sake of modernizing the East. He locates the backwardness of the East in women and, more importantly, men's attitude towards them. Their ignorance and idleness are both symptomatic and symbolic of what is wrong. Misogyny informs attitudes of both men and women towards life. For example, treating women as sexual objects - this is seen in encouraging women to care only for their appearance in the East-bespeaks of men's frivolity and ingrains them in a sex-obsessed lifestyle. While European men are hard at working towards tamaddun, Eastern men think only of sex. For al-Shidyāq, women are the problem in the East, and more importantly, women are men's problem. It is up to men to liberate women, to educate them, and to give them work. At the end the debate between zìr al-nis $\bar{a}^{\prime}$ and bakhis al-nis $\bar{a}^{\prime}$, the latter finally comes around to the former position and decides to educate his wife. He goes around town to look for an educated woman to teach his wife but to no avail. He again turns to zìr al-nis $\vec{a}^{2}$ who comes to his rescue one more time. Lo and behold, he has educated his wife and she is now ready to be the educator. She is promptly dispatched to bakhis al-nisā 's house to teach his wife.

Al-Sāq dramatizes this gendered tamaddun discourse, or discourse on modernization, and inscribes the project of tamaddun on the relationship between its twin protagonists, al-Fāriyāq and al-Fāriyāqiyya, and places the stake on their success as a couple. As I have already mentioned, their marriage comes at the end of a courtship on their shared rooftop, and he takes upon the task of educating her and 
allowing her to have a voice. His journey to Malta is made to seem entirely up to her. By the time they arrive there, she is his equal, sharing not only his views but also all decisions. They chat, debate, fight and make up. They walk down the street hand in hand. They go to dinner parties together and exchange views about all that they see. She moves freely indoors and outdoors, comes and goes as she wishes, mingles in mixed company openly, and often decides to stay behind when he travels on business, as in his first trip to Cambridge, or another trip to Tunis. Everything seems perfect for this very 'modern' couple. Their perfect happiness is, however, constantly threatened by his jealousy and, above all, his insecurity. He is always surprised to come home after a trip to find al-Fāriyāqiyya there, waiting for his return, and not having run off with another man. The fear of infidelity permeates $a l-S \bar{a} q$. The four maqāmāt in al$S \bar{a} q$ replay this fear of infidelity.

The narrator-protagonist, al-Hāāith Ibn Hishām, pronounced al-Hāris Ibn Hithām due to the narrator's speech defect, stays up one night pondering over the meaning of life in the first maqāma, and when he finds no satisfying answer in the Arabic 'classics' he takes to the street and chances upon al-Fāriyāq, who recites a long poem of his own composition that the narrator receives as the ultimate wisdom and returns home happy. The second maqāma, given the title 'to Make One Sit,' finds the narrator looking for answers about marriage and divorce among the scholars in Christian, Jewish and Muslim communities only to run into al-Fāriyāq again, who confirms in another poem the efficacy of divorce. The third maqama, 'to Make One Stand', offers the trials and tribulations of gender relations from the perspectives of both men and women, which al-Fāriyāq, yet again, confirms as the facts of life. 'A Maqāma to Make One Walk', the fourth, exposes women's wiles and men's fear of infidelity only for al-Fāriyāq to confirm their inevitability and display his insight into women's affairs. The four maqāmāt, embedded in and framed by al-Sāq, do not add to the substance of $a l-S \bar{a} q$, or for that matter, his discussions of women and gender in his other works, including his travelogues, al-Wāsita and Kashfal-mukhabba'. They do, however, simultaneously heighten the fear of infidelity and condense al-Shidyāq's play with word, genre and worldviews, the heart and soul of the entire al-Sāq, into four relatively short maqāmāt. These maqāmāt confine the mobility inherent in the genre in one city, making the journey a linguistic and conceptual one.

The fear of infidelity, overlapped with interlingual, intertextual and intercultural play with words, genres and worldviews here, is a trope around which al- 
Shidyāq narrates his tamaddun project constructed around gender-woman and woman-man relationship - that allows him to do two things at simultaneously: to articulate his vision for tamaddun, which is necessarily premised on intercultural entanglement, and at the same time act out the emotional turmoil that accompanies any major change. I draw attention to the exaggerated language of $a l-S \bar{a} q$ and its heightened dramatic moments. The entire book is a hyperbole. It is, moreover, an exaggeration of what has been iterated and reiterated pushed to extremity. Al-Sāq is a melodrama of heart and mind that externalizes the hysteria surrounding the emergence of a modern subject. Al-Fāriyāqiyya, as the nisba pattern of her derived name suggests, must be read less as al-Fāriyāq's wife having a separate existence from him but more as his alter ego, the other part of him existing within him that is striving to integrate into its own twin, to find coherence. Fear of infidelity makes a different kind of sense here. It is about insecurity of another sort. It taps into the vulnerability of the subject. What if it never coheres? This is central because tamaddun's success depends on the coherence of the subject. The coherence of the subject, however, is a matter of language, for language is the sum total of epistemology and ontology. 'Idhi 'l-lugha', al-Shidyāq says in al-Sāq, 'innama hiya 'ibaratun 'an harakati l-insān wa af'ālihi wa afkārihi (language is the vehicle of man's movement, action and thought), ${ }^{54}$ and shows us through his play with language in $a l-S \bar{a} q$ and the embedded maqāmāt. More significantly, al-Sāq is about laying bare the workings of language and how these show up the relationship between language and thought, language and culture, and language and subject.

Gender is central to his interrogation of language and its epistemological and ontological reaches and consequences. The crux of the matter here is less the division of the world into women and men, but more gendered thinking, or the construction of thought premised on polarized categories of thought, such as female v. male, right v. wrong, good v. bad, East v. West, Christian v. Muslim, Tradition v. Modern, to name but a few, and the taboos surrounding transgressing well-established categorical boundaries. The boundary between two polarized categories is not only fuzzy but elastic and, more importantly, it straddles two fabricated faces of the same thing dichotomized for a purpose that becomes clear when political decision, social conduct and ethical judgment are imposed, accepted or resisted as right or wrong, good or bad. The female, for example, is derived from the male, and the male encompasses the female. They are two dimensions of the same human, and it is nearly impossible to 
insist that the male is superior and the female inferior, and to lay evil at the female's door, on her desire, wile and sexuality.

Sexuality figures so heavily in $a l-S \bar{a} q$, and also the maqāmāt in al-Badr alsāfir, because it is the most convenient taboo issue at the centre of a worldview informing an Eastern human's every thought and action. It opens up cultural landscape, social etiquette and moral universe for deterritorialization and reterritorialization. It works on thinking, the configuration of abstract and invisible epistemological paradigms that are at the foundation of ontological choices. It binds two archetypal categories, the female and the male, together in such a way that one flows into another and the two, like Siamese twins, cannot and must not be separated. Thought, language and gender are inextricably twined in $a l-S a \bar{q}$, where inquiry into language and language-use here is framed by two simultaneous narratives: marriage and travel. During courtship, wedding and married life, relevant language is presented as both expressive of cultural norms structuring behaviour and ontological assertions. If a word exists in language, then the practice denoted by the word must be known and experienced and must be open to discussion and not suppressed as taboo. Women-men interaction is natural, for language is full of adjectives describing both men and women that embody their desire for each other. This desire in turn makes women and men naturally knowledgeable of each other. This gender discourse in turn frames, or is framed by another East-West discourse that is part and parcel of the travel account. The practices of the West are necessarily seen from the perspectives of two Easts, one female and another male. The East is in turn examined from the perspectives of new experiences, again female and male, gained in the West.

\section{Configurations of Multilingualism and World Literature}

Sexuality in al-Shidyāq is like that in al-Miknāsī: it is Barthesian 'secondary sexuality' situated not in sex but in text, for 'the pleasure of the text' derives from the interplay between language and thought and, here, creative inter-lingual, interconceptual and inter-cultural dialogue and playful interaction that generate both change and pleasure. This intercultural dialogue finds a creative outlet in the maqāmāt appended to and embedded in their texts, which re-narrate the rihla in a stringently grammaticalized language that brings within its seemingly monolingual fold the multilingualism of the speaking subjects and their environment. The monolingual veneer of the literary texts born in languages in dialogue is, in al-Miknāsī and al- 
Shidyāq, punctuated by an anxiety, here, of sexual infidelity that betrays the entanglement of languages, concepts and worldviews in their making. Al-Miknāsī and al-Shidyāq offer two 'multilingual locals,' each with a unique configuration of languages in dialogue. The eighteenth-century Western Mediterranean of al-Miknāsī is mapped by, to name but the main languages, Arabic, Italian and Spanish, and the interactions between Christians and Muslims over the question of captives, whereas the nineteenth-century Eastern Mediterranean of al-Shidyāq by Arabic, English and French, and the East-West intercultural encounter. Close readings of individual texts show us how each is produced, consumed and reproduced its own configuration(s) of multilingualism, and comparative readings make it visible the ways in which each configuration of multilingualism shapes and is reshaped in each text and, more importantly, creates and is recreated in language.

\footnotetext{
Notes

${ }^{1}$ David Crystal, The Cambridge Encyclopedia of the English Language (Cambridge: Cambridge University Press, 1995), 5.

${ }^{2}$ Robert McCrum, William Cran, and Robert MacNeil, The Story of English: A Companion to the PBS Television Series (New York: Viking Penguin, 1986), 51.

${ }^{3}$ Jacques Derrida, Monolingualism of the Other OR The Prosthesis of Origin, tr. Patrick Mensah (Stanford, California: Stanford University Press, 1996).

${ }^{4}$ Pascale Casanova, The World Republic of Letters, trans. Malcolm Debevoise (Cambridge, Mass: Harvard University Press, 2007).

${ }^{5}$ Francesca Orsini, 'The Multilingual Local in World Literature', Comparative Literature 67.4 (2015): 345-74.

${ }^{6}$ David Damrosch, What Is World Literature? (Princeton: Princeton University Press, 2003) and How to Read World Literature (Malden: Wiley-Blackwell, 2009).

${ }^{7}$ Franco Moretti, 'Conjectures on World Literature', New Left Review 1 (2000): 54-68; Graphs, Maps, Trees: Abstract Models for A Literary Theory (London and New York: Verso, 2005); and Distant Reading (London: Verso, 2013).

${ }^{8}$ Kees Versteegh, The Arabic Language (Edinburgh: Edinburgh University Press, 2001).

${ }^{9}$ Karla Mallette, Lives of the Great Languages: Arabic and Latin in the Medieval Mediterranean (Chicago: Chicago University Press, forthcoming in Spring 2021).

${ }^{10}$ For a quick assessment of his career and travel writing, see Nabil Matar, An Arab Ambassador in the Mediterranean World: the Travels of Muhammad ibn 'Uthmān al-Miknāsī (New York: Routledge, 2015).

${ }^{11}$ Roland Barthes, The Pleasure of the Text, English translation by Richard Miller (New York: Hill and Wang, 1973).

${ }^{12}$ References are made to Muhammad Ibn 'Uthmān al-Miknāsī, al-Iksīr fi fikāk al-asīr, ed. Muhammad Fāsī (Rabat: al-Markaz al-Jāmi '̄i li 1-Bahth al- 'Ilmīi, 1965).

${ }^{13}$ References are made to Muhammad İon 'Uthmān al-Miknāsī, al-Badr al-sāfir li-hidāyat al-musāfir ilā fikāk al-asārā min yad al- 'aduw al-kāfir, ed. Malīka al-Zāhidī (al-Muhammadiyya: Jāmi 'at alHasan al-Thānī, 2005).

${ }^{14}$ Reference is made to Muhammad Ibn 'Uthmān al-Miknāsī, Ihrāz al-mu 'allā wa l-raqīb fì hajj bayt allāh al-harām wa ziyārat al-quds al-sharīf wa l-khal̄̄l wa l-tabarruk bi-qabr al-habīb, ed. Muhammad Bū Kabbūt (Abu Dhabi and Beirut: Dār al-Suwaydī and al-Mu'assasa al- 'Arabiyya li 1-Nashr wa 1Tawzī', 2003).

${ }^{15}$ These include Aḥmad al-Hajarī Afūqāy’s Riḥlat al-Shihāb ilā liqā' al-aḥbāb, also known as Nāṣir al-dīn 'alā al-qawm al-kāfirīn (1611-1613), Muhammad al-Ghassān̄̄'s Riḥlat al-wazīr fì iftikāk al-asīr (1690-1691), and Aḥmad Ibn al-Mahdī al-Ghazzāl, Natījat al-ijtihād fì al-muhādana wa l-jihād (1766).
} 
Selections from the first two texts are available in English translation in Nabil Matar, In the Lands of the Christians: Arabic Travel Writing in the $17^{\text {th }}$ Century (New York: Routledge, 2003).

${ }^{16}$ The most famous Moroccan examples of the latter type are 'Alī Ibn Muhammad al-Tamagurūtī's alNafha al-miskiyya fì al-sifāra al-turkiyya (The Perfumed Breeze of Turkish Embassy, 1589) and Abū al-Qāsim al-Zayyān̄̄'s (1734-1833) al-Tarjumāna al-kubrā fì akhbār al-ma 'mūr barran wa-bahran (1817?).

${ }^{17}$ See Nabil Matar, Turks, Moors and Englishmen in the Age of Discovery (New York: Columbia University Press, 1999); and Europe Through Arab Eyes 1578-1727 (New York: Columbia University Press, 2009).

${ }^{18}$ References are made to Aḥmad Fāris al-Shidyāq, al-Wāsiṭa fì ma rifat aḥwāl māliṭa (Beirut: Dār alMadā, 2007); and the version of Kashf al-mukhabba' 'an funūn ūrūbbā published by Alexandria Library (Cairo: Dār al-Kitāb al-Miṣrī and Beirut: Dār al-Kitāb al-Lubnān̄̄, 2012). These two works were edited by Qāsim Wahba and published together in one volume (Abu Dhabi: Dār al-Suwaydī, 2004).

${ }^{19}$ See, Ian Richard Netton, Seek Knowledge: Thought and Travel in the House of Islam (RichmondSurry: Curzon Press, 1996); and Houari Touati and Lydia G. Cochrane, Islam and Travel in the Middle Ages (Chicago; London: University of Chicago Press, 2010).

${ }^{20}$ References are made to Aḥmad Fāris al-Shidyāq, al-Sāq 'alā al-sāq, ed. al-Shaykh Nasīb Wuhayba al-Khāzin (Beirut: Dār Matktabt al-Hayāt, n.d.).

${ }^{21}$ For studies of this work as autobiography, see Paul Starkey, 'Fact and Fiction in al-Sāq 'alā al-sāq', Writing the Self: Autobiographical Writing in Modern Arabic Literature, ed. Robin Ostle, Ed de Moor \& Stefan Wild (London: Saqi Books, 1998): 30-38; and 'Voyages of Self-definition: The Case of [Ahmmad] Fāris al-Shidyāq', Sensibilities of The Islamic Mediterranean: Self-expression in a Muslim culture from post-classical times to the present day, ed. Robin Ostle (London: I. B. Tauris, 2008): 118132.

${ }^{22}$ Philip F. Kennedy, 'The Maqāmāt as a Nexus of Interests: Reflections on Abdelfattah Kilito's Les Séances', in Julia Bray, ed., Writing and Representation in Medieval Islam (London; New York: Routledge, 2006): 153-214.

${ }^{23}$ See, for example, Alexander E. Elinson, Looking Back at al-Andalus: the Poetics of Loss and Nostalgia in Medieval Arabic and Hebrew Literature (Leiden; Boston: Brill, 2009); James T. Monroe, The Art of Badī‘ al-Zamān al-Hamadhān̄̄ as Picaresque Narrative (Beirut: American University of Beirut, 1983); Douglas C. Young, Rogues and Genres: Generic Transformation in the Spanish Picaresque and Arabic Maqāma (Newark Delaware Juan de la Cuesta, 2004); and David A. Wacks, Framing Iberia: Maqāmāt and Frametale Narratives in Medieval Spain (Leiden; Boston: Brill, 2007).

${ }^{24}$ See, for example, Ahmed Idrissi Alami, Mutual Othering: Islam, Modernity and the Politics of Cross-Cultural Encounters in Pre-Colonial Moroccan and European Travel Writing (Albany: Sate University of New York Press, 2013).

${ }^{25}$ Al-Miknāsī, al-Badr al-sāfir, 185-6.

${ }^{26}$ Al-Shidyāq, Kashf al-mukhabba', 428.

${ }^{27}$ Rebecca C. Johnson, 'Foreword' in Aḥmad Fāris al-Shidyāq, al-Sāq 'alā l-sāq, tr. Humphrey Davies, Leg Over Leg, 4 volumes, Library of Arabic Literature (New York: New York University Press, 2014). References are made to the paperback edition, Leg over Leg, 2 volumes (New York: New York University Press, 2015), 1: ix-xxxvi, xxxvi.

${ }^{28}$ Ibid.

${ }^{29}$ Al-Miknāsī, al-Badr al-sāfir, 186-190.

${ }^{30}$ Al-Shidyāq, Kashf al-mukhabba', 427-8.

${ }^{31}$ See Eric Calderwood, Colonial al-Andalus: Spain and the Making of Modern Moroccan Culture

(Cambridge Massachusetts: The Belknap Press of Harvard University Press, 2018).

${ }^{32}$ This is according to Malīka al-Zāhidī, who edited and introduced al-Badr al-säfir: 17-102, 37.

${ }^{33}$ Al-Miknāsī, al-Badr al-sāfir, 131-140.

${ }^{34}$ Ibid, 186-190.

35 Ibid, 188.

${ }^{36}$ Ibid, 273.

${ }^{37}$ Ibid, 275-332.

${ }^{38}$ Ibid, 271-273.

${ }^{39}$ Ibid, 312.

${ }^{40}$ Ibid, 275-278.

${ }^{41}$ See Malīka al-Zāhidī, footnote no. 783 in al-Badr al-sâfir, 275. 
42 yasser elhariry, Pacifist Invasions: Arabic, Translation and the Postfrancophone Lyric (Liverpool: Liverpool University Press, 2017), 20

${ }^{43}$ Ibid.

${ }^{44}$ Sulaymān Jubrān, Kitāb al-fāriyāq: mabnāhu wa uslūbuhu wa sukhriyatuhu (Tel Aviv: Tel Aviv University Press, 1991), 24-28.

${ }^{45}$ Fawwāz Ṭarābulsī and Azz al- 'Aẓma, Ahmmad Fāris al-Shidyāq (London: Riad el-Rayyes, 1995).

${ }^{46}$ Kamran Rastegar, Literary Modernity between Middle East and Europe: textual transactions in $19^{\text {th }}$ century Arabic, English and Persian Literatures (London: Routledge, 2007): 101-124.

${ }^{47}$ Ṭarābulsī and al-'Aẓma, Ahmad Fāris al-Shidyāq, 32.

${ }^{48} \mathrm{He}$ was invited to help translate the Bible into Arabic.

${ }^{49}$ Al-Shidyāq, al-Wāsița fì ma 'rifat aḥwāl Mālța, ed. Qāsim Wahba, 71-72

${ }^{50}$ Elsewhere, in $a l-J a w \bar{a} ' i b$ he makes an explicit plea for mixed society. Women may benefit from the knowledge of men she comes into contact with. I refer in particular to the essay (maqāla) on ' $F \bar{\imath} b a$ ' $d$ ' ahwāl takhușsu al-nisā' (observations on women's conditions)', in Ṭarābulsī and al- 'Aẓma, Ahmad Fāris al-Shidyāq, 284-303.

${ }^{51}$ Al-Shidyāq, al-Sāq, 391-404

${ }^{52}$ Al-Shidyāq, Kashfal-mukhabba', 171.

${ }^{53}$ Collected and published in two volumes as Kanz al-raghā' $i b$ fi muntajāt al-jaw $\bar{a}$ ' $i b$ (Istanbul: Mațba at al-Jawā'ib, 19871-1881). Al-Jawā' $i b$ was a newspaper he owned, managed and edited whilst in Istanbul 1860-1884

${ }^{54}$ Al-Shidyāq, al-Sāq, 522. 